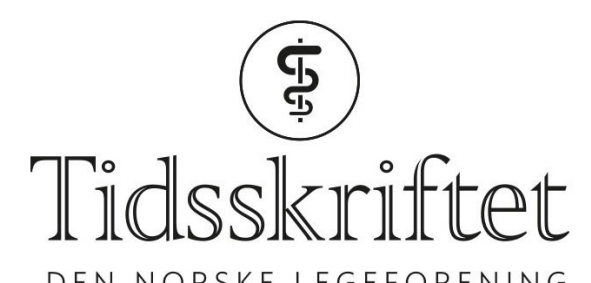

DEN NORSKE LEGEFORENING

\title{
Helsevesenet svikter transpersoner
}

KRONIKK

\section{ESBEN ESTHER P. BENESTAD}

E-post: esben.esther@uia.no

Esben Esther P. Benestad (f. 1949) er lege, familieterapeut og spesialist i klinisk sexologi NACS ved Grimstad MPAT-institutt og professor i sexologi ved Universitetet i Agder. Forfatter har fylt ut ICMJE-skjemaet og oppgir ingen interessekonflikter.

\section{JANECKE THESEN}

Janecke Thesen (f. 1951) er spesialist i allmennmedisin og i samfunnsmedisin og utdannet veileder i kvalitetsarbeid, kognitiv terapi og allmennmedisin. Hun er forsker ved Uni Research Helse. Forfatter har fylt ut ICMJE-skjemaet og oppgir ingen interessekonflikter.

\section{HAAKON AARS}

Haakon Aars (f. 1941) er spesialist i samfunnsmedisin, i psykiatri og i klinisk sexologi NACS. Han arbeider ved Institutt for Klinisk Sexologi og Terapi, Oslo.

Forfatter har fylt ut ICMJE-skjemaet og oppgir følgende interessekonflikter: Han har mottatt honorar fra Novartis AS og Lundbeck for undervisning om multippel sklerose og seksualitet.

\section{GUNNAR F. OLSEN}

Gunnar F. Olsen (f. 1957) er spesialist i allmennmedisin og fastlege i Oslo. Han er veileder i allmennmedisin, leder av Norsk forening for allmennmedisins utvalg for kvalitet og pasientsikkerhet (KUP) og styremedlem i Oslo legeforening.

Forfatter har fylt ut ICMJE-skjemaet og oppgir ingen interessekonflikter.

\section{MARI BJØRKMAN}

Mari Bjørkman (f. 1963) er ph.d., spesialist i allmennmedisin og fastlege i Oslo. Hun er leder av Norsk forening for allmennmedisins faggruppe for lesbisk, homofil, bifil og trans helse. Forfatter har fylt ut ICMJE-skjemaet og oppgir ingen interessekonflikter.

Det foreligger nå flere statlig finansierte studier og utredninger som omhandler eller berører helsetilbudet til transpersoner. Det finnes kunnskap og gode intensjoner i direktorat og departement. Likevel går det tregt å omsette kunnskapen til politikk og praktisk helsearbeid. 


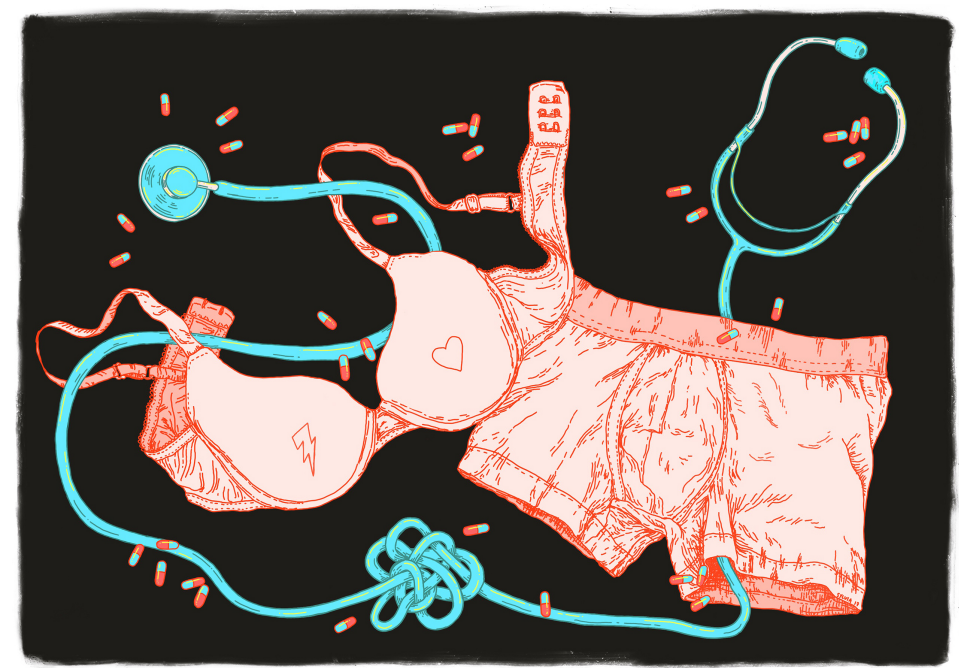

Illustrasjon: Sylvia Stølan

Flere undersøkelser bekrefter at trans*delen av befolkningen er større enn tidligere antatt, det vil si mer enn 1\% (1) (ramme 1). Denne delen av befolkningen - også kalt de kjønnsinkongruente - har dårligere helsekvalitet enn befolkningen for øvrig (2). Samtidig ser vi at mange har gode liv med god helse og god livskvalitet. Det er ingen automatikk i at uvanlige menneskelige talenter fører til redusert helse og livskvalitet. Utenforliggende forhold må ligge til grunn til at det blir slik, for eksempel hvilke helsetilbud og hvilken helseprofesjonell kompetanse som foreligger og utøves.

RAMME 1 BEGREPSAVKLARING

- Trans* er et samleuttrykk som benyttes når vi omtaler personer som opplever manglende samsvar mellom kjønnsidentitet eller kjønnsuttrykk og det juridiske kjønnet som personen fikk tildelt ved fødsel. Dette er ingen ensartet gruppe, og uttrykket omfatter personer som selv beskriver seg som transperson eller transkjønnet, personer med diagnosen transseksualisme og personer som har forskjellige kjønnsuttrykk og eventuelt veksler mellom disse. Stjernen i trans* brukes for å vise til hele transspekteret og for å vise til mangfoldigheten blant mennesker som definerer seg som transpersoner

- Kjønnsidentitet er en persons indre opplevelse av å være kvinne, mann, både kvinne og mann, transperson eller ingen av delene

- Kjønnsinkongruens viser til opplevelsen av manglende samsvar mellom egen kjønnsidentitet eller kjønnsuttrykk og det kjønnet man ble tillagt ved fødselen

- Kjønnsdysfori betegner ubehag forårsaket av manglende samsvar mellom kjønnsidentitet og det kjønnet man ble tillagt ved fødselen

- Seksuell helse kan defineres som fysisk, mental og sosial velvære relatert til seksualitet. Seksualitet omfatter følelser, tanker og handlinger, i tillegg til det fysiologiske og fysiske

- Faggruppene står sentralt i Norsk forening for allmennmedisins faglige aktiviteter. En faggruppe arbeider med et felt innenfor allmennmedisinen. Faggruppen for lesbisk, homofil, bifil og trans helse har hjemmesiden http://legeforeningen.no/Fagmed/Norsk-forening-for-allmennmedisin/Faggrupper/les bisk-og-homofil-helse/ 
Forfatterne av denne kronikken sitter i faggruppen for lesbisk, homofil, bifil og trans (LHBT) helse i Norsk forening for allmennmedisin (NFA). Faggruppen (tidligere kalt referansegruppe) står sentralt i foreningens faglige aktiviteter. I denne kronikken fokuserer vi på de kjønnsinkongruente.

Kjønnsinkongruens erstatter «trans» som begrep og viser til opplevelsen av manglende samsvar mellom egen kjønnsidentitet eller kjønnsuttrykk og det kjønnet vi blir tillagt ved fødselen. Den subjektive opplevelsen av å være kvinne, mann, både kvinne og mann, noe tredje eller ingen av delene, beskrives som vår kjønnsidentitet. Når denne identiteten er inkongruent med kjønnet tillagt ved fødselen, skaper det en smerte, gjerne omtalt som kjønnsdysfori. Denne dysforien skaper uhelse og skulle dermed være et prioritert mål for ethvert helsevesen. Vi ser altfor lite til den prioriteringen. Det er til å undres over, ettersom den norske staten selv har forestått undersøkelser og rapporter, som alle påpeker dette.

\section{Kunnskapsgrunnlaget}

I en rapport på oppdrag fra Bufdir fra 2012 om barn med alternative kjønnsuttrykk ble behovet for kompetanseheving og holdningsendrende arbeid vektlagt (3). Forfatterne foreslo at disse barna skulle få oppfølging fra lokale familierådgivningskontor, men at kompetansehevingen ikke kunne forventes å omfatte alle familierådgivningskontor. Man foreslo at noen, likelig fordelt over hele landet, ble valgt til oppdraget.

I 2013 kom en annen Bufdir-finansiert undersøkelse, Alskens folk. Levekår, livssituasjon og livskvalitet for personer med kjønnsidentitetstematikk (4). Rapporten fremhevet to funn: For det første at både skole, arbeidsplass, familie og andre offentlige institusjoner generelt har mangelfulle kunnskaper om, og lite forståelse for, kjønnsidentitetstematikk. For det andre at helsevesenet svikter gruppen med kjønnsinkongruens.

I april 2015 leverte en ekspertgruppe oppnevnt av Helsedirektoratet utredningen Rett til rett kjønn - helse til alle kjønn (5). Mandatet var å utrede vilkår for endring av juridisk kjønn og organisering av helsetjenester for personer med kjønnsinkongruens og kjønnsdysfori.

Det ledet til ny lov om juridisk kjønn. Frem til juni 2016 var det krav om at reproduktive organer måtte fjernes for å få tillatelse til kjønnsendring i Folkeregisteret. Nå er en egenerklæring til registeret tilstrekkelig. Kravet om kroppslige endringer er falt bort. Til nå har mer enn 700 benyttet anledningen til å bestemme eget juridisk kjønn, uavhengig av kjønn tildelt ved fødselen og uavhengig av kroppslige endringer. Rapporten slo også fast at det er en rekke mangler og utfordringer ved dagens tjenestetilbud. Mange med rett til helsehjelp tilknyttet kjønnsdysfori får ikke den hjelpen de har behov for og ønsker.

Rapporten ga gode og grundige anbefalinger om hvordan helsetjenesten burde organiseres for å imøtekomme kjønnsinkongruentes behov for helsehjelp. Dette er ennå ikke implementert.

I januar 2017 kom handlingsplanen Snakk om det! Strategi for seksuell helse (2017-22) fra Helseog omsorgsdepartementet (6). Den erstattet to separate handlingsplaner som har fokusert på hiv og uønskede svangerskap. En klar målsetning var å tydeliggjøre betydningen av seksuell helse. Strategien understreket at alle mennesker i alle aldre skal sikres god kunnskap og nødvendig kompetanse til å ivareta egen seksuell helse, og god seksuell helse skal sikres for hele befolkningen. Helsevesenet skal sikre kunnskap om og ivaretagelse av seksuell helse i helse- og omsorgstjenesten. Helsepersonell skal respektere og forstå brukere og pasienters seksuelle behov. Når og ikke minst hvordan har våre helsemyndigheter tenkt å omsette kunnskapen i praksis?

\section{Omorganiser helsetilbudet nå!}

Vi støtter konklusjonen i rapporten Rett til rett kjønn, helse til alle kjønn om at personer som opplever kjønnsdysfori skal tilbys kompetent helsehjelp på det nivå i helsetjenestene den enkelte har behov for. Ekspertgruppens klare flertall anbefaler helsetilbud etter to hovedprinsipper: Behandlingstilbudet bør legges opp etter laveste effektive omsorgsnivå 
(LEON), og helsetilbudet skal tilstrebe minste effektive dose. Det betyr at pasienter som utelukkende ønsker kroppsjusterende hormonbehandling, skal få tilgang til dette uten krav om å gjennomgå kirurgiske justeringer. Der bare større eller mindre kirurgiske justeringer er ønsket, skal det ikke være krav om hormonell behandling.

Helsetjenesten i Norge er organisert nettopp etter LEON-prinsippet, der fastlegen skal være tilgjengelig for alle typer pasienter og problemstillinger og være pasientens portåpner og koordinator. Fastlegen må ikke kunne alt, men må kunne håndtere alt. Per i dag gjelder ikke det for kjønnsinkongruente. For å kunne håndtere problemstillinger innen kjønnsidentitetsproblematikk, kjønnsinkongruens og kjønnsdysfori må fastlegen ha spesialister å samarbeide med. Spesialisttilbudet utgjøres i dag av tredjelinjetjenesten ved Oslo universitetssykehus (7). På avdelingens hjemmeside står det: «Ved mistanke om transseksualisme skal fastlegen henvise deg til din lokale Barnepsykiatriske poliklinikk (BUP) eller Distriktspsykiatriske poliklinikk (DPS). BUP/DPS skal da gjennomføre en psykiatrisk utredning og henvise deg videre til Nasjonal behandlingstjeneste for transseksualisme (NBTS) ved Oslo universitetssykehus.» Her oppstår tre problemer. For det første forutsetter den nasjonale behandlingstjenesten at man vil være enten mann eller kvinne og endre til kjønnet som er motsatt av det man fikk tildelt ved fødsel. De som ikke passer inn i dette mønsteret, får ikke tilbud om behandling. For det andre finnes det ikke en regional annenlinjetjeneste for hormonell eller kirurgisk behandling. For det tredje skyves fastlegen ut på sidelinjen.

Det fremgår av rapportene Alskens folk (4) og Rett til rett kjønn, helse til alle kjønn (5) at tilbudet på Rikshospitalet har fungert for restriktivt og at mange har falt utenfor og at det i seg selv har medført psykisk uhelse. Mange ønsker ikke en størst mulig endring til det motsatte kjønn. Hvis «Petter» bare trenger en parykk for å bli «Petrine», bør fastlegen kunne skrive attesten som gir økonomisk støtte til dette. Hvis «Petrine» kanskje også trenger hormonbehandling eller kirurgi, bør fastlegen ha kjennskap til den typen hormonbehandling og ha tilgang til en fungerende annenlinjehelsetjeneste innen helseforetaket å konferere med eller henvise til, slik det er innen de fleste fagdisipliner. Dette er klare anbefalinger i rapporten. Nå må det implementeres!

\section{Vi trenger sexologisk kompetanse}

Både indirekte og direkte påpeker de ovennevnte rapportene behov for å heve den sexologiske kompetansen i helsevesenet. Leger med sexologisk kompetanse vil være et godt supplement til sykehuspoliklinikkene i behandlingen av kjønnsinkongruente. Videre er det vanskelig å se for seg hvordan Strategi for seksuell helse 2017-2022 (6) skal kunne

implementeres uten å benytte den kompetansen som faktisk allerede eksisterer. Det finnes allerede to videreutdanningsløp innen sexologi. Den ene er spesialist $i$ sexologisk rådgivning, den andre er spesialist $i$ klinisk sexologi. Disse er bygd opp etter spesialiseringsmalene fra både medisinske og psykologiske spesialistutdanninger. De godkjennes i dag av en nordisk godkjenningsgruppe organisert av Nordic Association for Clinical Sexology. Norske helsemyndigheter burde formalisere også disse tilleggsutdanningene.

I Strategi for seksuell helse 2017-2022 står det: "God seksuell helse er en ressurs- og beskyttelsesfaktor som fremmer livskvalitet og mestringsferdigheter. Seksualitet omfatter følelser, tanker og handlinger, i tillegg til det fysiologiske og fysiske». Dette angår alle.

LITTERATUR:

1. Clark TC, Lucassen MF, Bullen P et al. The health and well-being of transgender high school students: results from the New Zealand adolescent health survey (Youth'12). J Adolesc Health 2014; 55: 93 - 9. [PubMed][CrossRef]

2. Clements-Nolle K, Marx R, Katz M. Attempted suicide among transgender persons: The influence of gender-based discrimination and victimization. J Homosex 2006; 51: 53 - 69. [PubMed][CrossRef] 
3. Hawke AEV, Aursand PC, Hole LR et al. Hva trenger barn med alternativt kjønnsuttrykk og deres familier? Prosjekt for tjenesteutvikling på LHBT-feltet i familievernet. Oslo: Bufetat, 2012.

4. Van der Roos J. Alskens folk. Levekår, livssituasjon og livskvalitet for personer med kjønnsidentitetsproblematikk https://www.bufdir.no/bibliotek/Dokumentside/?docIdBUFoooo1926 (4.9.2017).

5. Helsedirektoratet. Rett til rett kjønn - helse til alle kjønn. Utredning av vilkår for endring av juridisk kjønn og organisering av helsetjenester for personer som opplever kjønnsinkongruens og kjønnsdysfori https://www.regjeringen.no/no/dokumenter/rett-til-rett-kjonn-helse-til-alle-kjonn/id2405266/ (4.9.2017).

6. Helse- og omsorgsdepartementet. Snakk om det! Strategi for seksuell helse (2017-2022). https://www.regjeringen.no/no/dokumenter/snakk-om-det/id2522933/(4.9.2017).

7. Nasjonal behandlingstjeneste for transseksualisme. 2017. https://oslo-universitetssykehus.no/behandlinger/transseksualisme-pa-ulleval-sykehus (28.8.2017).

Publisert: 13. november 2017. Tidsskr Nor Legeforen. DOI: 10.4045/tidsskr.17.0422 Mottatt 8.5.2017, første revisjon innsendt 30.7.2017, godkjent 4.9.2017.

(C) Tidsskrift for Den norske legeforening 2020. Lastet ned fra tidsskriftet.no 